\section{Development of a food frequency questionnaire in a probabilistic sample of adults from Niterói, Rio de Janeiro, Brazil}

\author{
Desenvolvimento de questionário de freqüência \\ alimentar em amostra probabilística de adultos \\ de Niterói, Rio de Janeiro, Brasil
}

\begin{abstract}
\end{abstract}
${ }_{1}$ Departamento de Nutrição Social, Universidade Federal Fluminense, Niterói, Brasil. 2 Escola Nacional de Saúde Pública Sergio Arouca, Fundação Oswaldo Cruz, Rio de Janeiro, Brasil.

${ }^{3}$ Escola Nacional de Ciências Estatísticas, Instituto Brasileiro de Geografia e Estatística, Rio de Janeiro, Brasil.

4 Programa de Pós-graduação em Saúde Coletiva, Universidade do Vale do Rio dos Sinos, São Leopoldo, Brasil.

Correspondence L. A. Anjos Laboratório de Avaliação Nutricional e Funcional, Departamento de Nutrição Social, Universidade Federal Fluminense.

Rua Mario Santos Braga 30 , sala 415, Niterói, RJ 24020-140, Brasil. lanjos@gmail.com
With the purpose of generating a list of foods for a food-frequency questionnaire, data from $24 \mathrm{~h} d i$ etary recalls on a typical day from a probabilistic sample of 1,724 adults of Niterói, Rio de Janeiro, Brazil, were analyzed. The frequency of food intake, the total intake of energy and macronutrients and the relative contribution of each food item to total energy and macronutrient intake were calculated. The most frequently reported food items (> 50\% of adults) were rice, coffee, beans, refined canesugar, and bread. Whole milk was consumed more frequently then skimmed milk or semi-skimmed milk. Beef was consumed by more adults than chicken, pork or fish. Approximately $90 \%$ of energy and macronutrients intake was explained by 65 food items. The list of food items generated in the present analysis is similar to those found in other samples of adults from urban areas in Brazil. It may be possible to generate a core list of common foods with addition of regional foods to be used nationally in urban areas of the country.

Food Consumption; Diet Surveys; Epidemiologic Methods
Luiz Antonio dos Anjos 1,2

Vivian Wahrlich 1

Mauricio Teixeira Leite de Vasconcellos 3

Danielle Ribeiro de Souza 1

Maria Teresa Anselmo Olinto 4

William Waissmann 2

Ruth Liane Henn 4

Sinara Laurini Rossato 4

Ana Eliza Port Lourenço 2

Ana Weigert Bressan 4

\section{Introduction}

Shifts in epidemiological profiles coupled with a global rise in the burden of chronic non-communicable diseases (CNCD) have lead to increased research attention on a possible relationship between these diseases and life-style, particularly food intake and physical activity 1 . Characterizing the pattern of food intake in a population is the swiftest way of identifying the risk of developing CNCDs secondary to diet. Given that current recommendations advise an active life style and control over food intake 2,3 , validated instruments for assessing dietary patterns in the Brazilian population are needed.

Food frequency questionnaires (FFQ) have been described by many authors as the most suitable method of identifying and describing dietary patterns in epidemiological studies ${ }^{4}$ due to their low cost and ease of use. Several previous attempts to devise an FFQ for use in the Brazilian adult population have been undertaken 5 . The first FFQ validated in Brazil was the instrument proposed by Sichieri \& Everhart 6, which was based on information gathered from the National Food Consumption and Family Budget Survey (ENDEF) carried out by the Brazilian Institute of Geography and Statistics (IBGE) between 1974 and 1975. The list of foods included the 61 most-frequently consumed foods according to the ENDEF, plus 12 food items deemed by the authors as important in the contemporary 
Brazilian diet but not included in the original ENDEF list 7 .

Based on the Sichieri \& Everhart 6 or food intake recorded among convenient samples of healthy individuals or groups with a specific disease, many questionnaires were developed in Brazil for application in interviews, as self-reports or over the Internet 8,9,10,11,12,13,14,15.

Recently, Fisberg et al.16 reported the creation of an FFQ among a population-based sample from the municipality of São Paulo, Brazil. The final FFQ comprised a list of 59 food items for men, 60 for women and 60 for both genders, with four portion sizes (small, medium, large and extra-large).

The aim of the present study was to devise an FFQ specifically for assessing dietary intake of energy and macronutrients, based on food intake data from a probabilistic sample of adults from Niterói, Rio de Janeiro, Brazil.

\section{Methods}

The food intake data was drawn from the Nutrition, Physical Activity and Health Survey (PNAFS), a household survey involving a probabilistic representative sample of adults living in Niterói conducted in 2003. The procedures were approved by the Institutional Review Board of the Sergio Arouca National School of Public Health of the Oswaldo Cruz Foundation.

The municipality of Niterói in the metropolitan region of Rio de Janeiro covers a territory of $131 \mathrm{~km}^{2}$ containing 143,924 households with a total of 459,451 residents, consisting of 213,984 men and 246,467 women according to the 2000 Demographic Census 17.

The main sampling characteristics of the PNAFS have been described elsewhere 18,19. Briefly, the sample was designed in three stages (census enumeration area - CEA, household and individual) using the inverse sampling technique 20. For the first stage, 110 CEAs with probability proportional to its numbers of households were systematically selected after CEA frame ordering by mean household's head income that corresponds to an implicit CEA stratification by income. The second stage entailed selection, with equal probability, of the household addresses to be visited until 16 successful interviews were conducted per CEA. In the third stage, one adult (age $\geq 20$ years) from each household was selected, with equal probability, from all those who met the inclusion criteria of the study. Using this approach, a total of 1,760 adults were selected to take part in the study.

In previous visits to each selected household, a pair of trained researchers explained the aims of the survey and the method of data collection. After obtaining the consent and signatures of the participants (free and informed consent term), the time and date of the initial survey was scheduled. On the scheduled day, information on the level of schooling, occupation and monthly household income was collected. Measures of body mass $(\mathrm{kg})$ were taken using portable electronic scales (Soehnle, Murrhardt, Germany or Seca, Birmingham, UK), and stature measured (cm) on a portable stadiometer (Seca) 18. The following day, the interviewer returned to the domicile to conduct the interview, in which interviewees retrospectively reported all activities carried out and food ingested over the past 24 hours (24-hour food recall - 24hR). To facilitate the estimation of food portion sizes, the interviewer displayed photographs of foods from a photographic record used for dietary questionnaires 21 in addition to separate photographs of foods not contained in the photographic record but identified as frequently consumed in a pilot study. When a food item cited by the interviewee was not present in the photographic record, the photo of another item having a similar portion size to that consumed was used.

Data collection was performed throughout 2003 (January-December), divided evenly in terms of time, in order to have the CEA of all household per capita income deciles being interviewed in each survey period. This procedure was adopted in order to minimize the possible influence of seasonality on food intake among individuals of all social strata.

The foods consumed were transcribed to an electronic spreadsheet in the raw form in which they were reported by interviewees, and the nomenclature was later standardized after completion of the data collection.

The weight in grammes of foods and preparations reported in the $24 \mathrm{hR}$ were estimated based on the weight in grammes contained in the photographic record. When a food item cited was not present in the photographic record, its weight in grammes was determined by weighing the food item at the reference portion size indicated in the photographic record. The preparations not included in the photographic record (e.g. sardine pie, Piamontese rice, Italian type savory, sweet tart or pavé, jelly, cream of peas, icepops, etc.) were prepared at the Nutrition and Dietetics Laboratory of the Social Nutrition Departament, Fluminense Federal University, based on the reference portion in the photographic record.

The foods and preparations reported in domestic measures (spoonfuls, ladles, beakers, teacups etc.) were converted to grammes using the Table for Assessment of Food Intake in Household 
Measures 22. Foods not listed in the table were weighed or in some cases prepared. For foods which had similar recipes e.g. shrimp patties instead of chicken filling (listed in table), the table recipe was used, replacing the different ingredients at quantities used.

For preparations consumed outside the home setting (at restaurants, bar/cafés etc.) and for processed foods (such as biscuits, ready foods, yoghurts, wholemeal bread, low-fat/sugar products), the respective suppliers were contacted by phone, or their internet site accessed, in order to collect weight in grammes along with nutritional information whenever possible. When this information was not available, the recipe was prepared in the Nutrition and Dietetics Laboratory and the reported portion size was weighed.

After converting the measures of foods and preparations into grammes, the Nutrition Decision Support System 23 was used to convert these into energy, carbohydrate, fats and proteins values. Data for foods or preparations not contained in the program were sourced from tables of food chemical compositions in the following order: IBGE 24, Franco 25, Pinheiro et al. 22, Philippi 26, Ulene 27 or sourced from the nutritional information obtained in the laboratory as described above.

Of the 1,760 individuals recruited, data on 36 individuals could not be assessed (2 were fasting) giving a final sample of food intake data for 1,724 individuals (1.202 women). The sample weights were calculated as the inverse of the product of the inclusion probabilities in each stage and then they were calibrated by the integrated household weighting system to adjust for gender and age selection bias, a common occurrence in household surveys. This procedure ensured coherence of the estimates with known population totals for the post-strata formed by gender and age groups 28 .

A total of 1,282 foods were reported, grouped into 143 items (foods/groups) with common characteristics. The relative contribution of each food item in terms of total energy and macronutrient intake was calculated for each individual using the procedure described by Block et al 29 . This consisted of the ratio between estimated total energy or macronutrients of the food consumed and the estimated corresponding total in the population as a whole, calculated by tallying all portions of all foods ingested as set forth in the equation below:

$$
C_{i}=\frac{100 \times \sum_{j=1}^{1724} w_{j} \times \sum_{k=1}^{S_{i j}} \text { Nutr }_{i j k}}{\sum_{i=1}^{143} \sum_{j=1}^{1724} w_{j} \times \sum_{k=1}^{S_{i j}} \text { Nutr }_{i j k}} \text { where, }
$$

$\mathrm{CR}_{\mathrm{i}}$ : is the relative contribution in percentage of energy or nutrient the food $i$ (i ranging from 1 to 143) to total energy or nutrient; Nutr $r_{i j k}$ : is the quantity of energy or nutrient of the portion $k(k$ ranging from 1 to $S_{i j}$ ) of food $i$ consumed by person $\mathrm{j}$ ( $\mathrm{j}$ ranging from 1 to 1,724 ), and is set to zero if the person did not consume this food; $\mathrm{S}_{\mathrm{ij}}$ : is the total portions of food $i$ which person $j$ consumed; $\mathrm{S}_{\mathrm{ij}}$ $\sum_{k=1}$ Nutr $_{i j k}:$ is the total energy or nutrient of all portions of food $\mathrm{i}$ consumed by person $\mathrm{j}$; and $\mathrm{w}_{\mathrm{j}}$ : is the calibrated sampling weight of person $j$.

All results in this study were obtained using the procedures of the SAS program, version 9.1 (SAS Inst., Cary, USA) for microcomputers, based on sampling weights and structural information from the sample design.

\section{Results}

The adult population of Niterói had a mean age (standard error) of 45.3 (0.6) and 43.0 (0.7) years, for men and women, respectively. Approximately $50 \%$ of the population were overweight (BMI $\geq$ $25 \mathrm{~kg} / \mathrm{m}^{2}$ ) and around $70 \%$ had finished at least first grade.

The most frequently consumed foods by adults included white rice $(80.9 \%)$ and coffee ( $80.5 \%)$, followed by black beans $(69.9 \%)$, refined sugar $(63.8 \%)$ and bread rolls $(57.5 \%)$. Whole milk (28.5\%) was consumed by more adults than skimmed (13.2\%) or semi-skimmed (9.4\%) milk and $31.3 \%$ of the population consumed softdrinks. It is noteworthy that only five foods were reported by more than $50 \%$ of the population. All other foods were reported by less than a third of the population.

Table 1 contains the list of food items that, taken together, account for approximately $90 \%$ of the total energy (90.2\%), protein $(93.2 \%)$, carbohydrate $(89.4 \%)$ and fat $(90.5 \%)$ intake of the adult population of Niterói. These results reveal that a group of 65 foods attains this percentage contribution of energy and macronutrients. Table 1 also shows median intake of each food in grammes, along with the equivalent number of portions in household measures.

\section{Discussion}

Gathering knowledge and monitoring dietary pattern of a population are important activities in societies undergoing socio-demographic changes which may have a significant impact on the diet of the population, as is the case for the 
Table 1

List of food items, their contributions (\%) in terms total energy, protein, carbohydrate and fats, median weight (g) and equivalent portions in household measures, of the intake in the adult population of Niterói, Rio de Janeiro, Brazil. Nutrition, Physical Activity and Health Survey (PNAFS), 2003.

\begin{tabular}{|c|c|c|c|c|c|c|}
\hline Food item & Energy (\%) & Protein (\%) & Carbohydrate (\%) & Fats (\%) & Median (g) & $\begin{array}{l}\text { Household measure } \\
\text { (number of portions) * }\end{array}$ \\
\hline White rice & 10.52 & 3.97 & 16.31 & 3.43 & 100 & Soup spoons (4) \\
\hline French bread rolls & 7.45 & 5.56 & 10.68 & 2.45 & 50 & Units (1) \\
\hline Black beans & 5.69 & 8.41 & 7.16 & 1.28 & 90 & Level medium ladle (1) \\
\hline Refined sugar & 5.35 & 0.00 & 9.85 & 0.00 & 20 & Teaspoons (4) \\
\hline Roast meat & 4.18 & 8.58 & 0.00 & 9.48 & 130 & Large slice (1) \\
\hline Beef steak & 3.21 & 9.12 & 0.04 & 5.70 & 120 & Medium unit (1) \\
\hline Stewed/Broiled/Roast chicken & 3.04 & 11.00 & 0.01 & 4.03 & 120 & Serving spoons (3) \\
\hline Whole milk & 2.91 & 3.19 & 1.89 & 4.69 & 156 & Small mug (1) \\
\hline Soft drink & 2.55 & 0.00 & 4.69 & 0.00 & 306 & Small glass beaker (1.5) \\
\hline Margarine & 2.03 & 0.01 & 0.00 & 7.08 & 13 & Teaspoons (3.3) \\
\hline $\begin{array}{l}\text { Salted biscuit (salted crackers, } \\
\text { cream crackers) }\end{array}$ & 1.98 & 0.91 & 2.31 & 2.01 & 40 & Units (5) \\
\hline $\begin{array}{l}\text { Roasted savory snack (patty, Arabic } \\
\text { turnovers, Italian, cheesebread) }\end{array}$ & 1.79 & 1.41 & 1.16 & 3.24 & 110 & Units (2) \\
\hline Banana & 1.74 & 0.52 & 2.95 & 0.18 & 120 & Medium units (3) \\
\hline Sliced bread & 1.65 & 1.32 & 2.49 & 0.24 & 50 & Slices (2) \\
\hline Cordials & 1.65 & 0.15 & 2.96 & 0.05 & 224 & Small glass beaker ( 1 ) \\
\hline Fried fish & 1.6 & 2.97 & 0.12 & 3.60 & 170 & Medium fillet (1.4) \\
\hline Minas cheese & 1.58 & 2.73 & 0.01 & 3.87 & 30 & Medium slice (1) \\
\hline Pizza & 1.49 & 1.60 & 1.35 & 1.71 & 392 & Medium slices (4) \\
\hline Spaghetti & 1.4 & 0.93 & 1.92 & 0.68 & 113 & Serving tongues (1) \\
\hline Basic sponge cake & 1.29 & 0.47 & 1.34 & 1.68 & 50 & Medium slice (1) \\
\hline Manioc & 1.12 & 0.15 & 1.42 & 1.13 & 233 & Pieces (3) \\
\hline Beer & 1.08 & 0.47 & 1.84 & 0.00 & 900 & Small glass beakers (4.5) \\
\hline Fresh juice & 1.07 & 0.22 & 1.85 & 0.09 & 224 & Small glass beaker (1) \\
\hline Sweet biscuits (wheat/corn flour) & 1.05 & 0.49 & 1.33 & 0.84 & 30 & Units (6) \\
\hline Potato fries or French fries & 1.02 & 0.32 & 0.89 & 1.70 & 50 & Serving spoons (1) \\
\hline Fried chicken & 0.98 & 3.35 & 0.01 & 1.40 & 120 & Pieces (medium drumstick) (2) \\
\hline Stewed meat & 0.97 & 2.43 & 0.08 & 1.79 & 120 & Soup spoons (4) \\
\hline Italian sausage & 0.97 & 1.08 & 0.03 & 2.67 & 66 & Units of sausage (1) \\
\hline Sweet filled biscuits (creams) & 0.88 & 0.23 & 0.91 & 1.23 & 45 & Units (3) \\
\hline Crisp chicken & 0.88 & 1.64 & 0.33 & 1.48 & 100 & Small fillet (1) or Nuggets (4) \\
\hline Pork & 0.84 & 1.51 & 0.00 & 2.04 & 176 & Pieces (2) \\
\hline Ground meat & 0.83 & 2.10 & 0.05 & 1.57 & 60 & Serving spoons (1) \\
\hline Butter & 0.82 & 0.02 & 0.00 & 2.85 & 10 & Teaspoons (2.5) \\
\hline Boiled or roast potatoes & 0.76 & 0.35 & 1.27 & 0.04 & 90 & Soup spoons (3) \\
\hline Skimmed milk & 0.75 & 1.62 & 0.79 & 0.15 & 156 & Small mug (1) \\
\hline Chocolate/Chocolates & 0.69 & 0.24 & 0.86 & 0.63 & 20 & Units of chocolates (1) \\
\hline Mild hard cheese/Mozzarella & 0.68 & 1.06 & 0.01 & 1.72 & 20 & Medium slice (1) \\
\hline Semi-skimmed milk & 0.66 & 0.89 & 0.62 & 0.58 & 170 & Small mug (1) \\
\hline Sweet bread & 0.63 & 0.41 & 0.88 & 0.31 & 82 & Units (1) \\
\hline Cream cheese & 0.61 & 0.66 & 0.10 & 1.54 & 30 & Soup spoons (1) \\
\hline Milk bread & 0.58 & 0.45 & 0.86 & 0.14 & 70 & Medium unit (1) \\
\hline Wholemeal bread & 0.58 & 0.52 & 0.82 & 0.17 & 60 & Slices (2) \\
\hline $\begin{array}{l}\text { Fried savory snack (chicken rissole, } \\
\text { pastel, Arabic beef dumpling) }\end{array}$ & 0.5 & 0.45 & 0.29 & 0.93 & 50 & Party-size units (2) \\
\hline $\begin{array}{l}\text { Hamburger. cheeseburger, ham and } \\
\text { cheese filled pittabread }\end{array}$ & 0.48 & 0.55 & 0.27 & 0.86 & 151 & Units (1) \\
\hline Apple & 0.46 & 0.05 & 0.8 & 0.07 & 181 & Units (1) \\
\hline
\end{tabular}

(continues) 
Table 1 (continued)

\begin{tabular}{|c|c|c|c|c|c|c|}
\hline Food Item & Energy (\%) & Protein (\%) & Carbohydrate (\%) & Fats (\%) & Median (g) & $\begin{array}{l}\text { Household measure } \\
\text { (number of portions) * }\end{array}$ \\
\hline Salted/Sundried/Jerked beef & 0.45 & 0.66 & 0.00 & 1.17 & 54 & Soup spoons (3) \\
\hline Stewed or poached fish & 0.45 & 1.92 & 0.04 & 0.35 & 160 & Medium fillet (1.3) \\
\hline Vegetable soup & 0.44 & 0.39 & 0.42 & 0.52 & 260 & Medium ladles (2) \\
\hline Meatballs & 0.42 & 0.82 & 0.10 & 0.81 & 150 & Units (3) \\
\hline Guava/Fig jam/Marmalade & 0.42 & 0.03 & 0.76 & 0.01 & 62 & Slices (1) \\
\hline Papaya & 0.41 & 0.14 & 0.69 & 0.04 & 268 & Units of small papaya (1) \\
\hline Potato pure & 0.40 & 0.19 & 0.45 & 0.43 & 80 & Serving spoons (1) \\
\hline Seasoned manioc flour mix & 0.38 & 0.05 & 0.44 & 0.45 & 20 & Level soup spoons (2) \\
\hline Processed juice & 0.38 & 0.04 & 0.68 & 0.01 & 192 & Small glass beaker (1) \\
\hline Frankfurter sausage & 0.38 & 0.53 & 0.03 & 0.95 & 50 & Units (1) \\
\hline Fried egg & 0.37 & 0.57 & 0.01 & 0.94 & 50 & Units (1) \\
\hline Orange & 0.36 & 0.14 & 0.60 & 0.04 & 180 & Medium units (1) \\
\hline Ham & 0.35 & 0.49 & 0.01 & 0.92 & 27 & Small slices (2) \\
\hline Cow's liver & 0.34 & 0.95 & 0.07 & 0.49 & 80 & Units (1) \\
\hline Yoghurt & 0.32 & 0.27 & 0.40 & 0.19 & 120 & Tub (1) \\
\hline Ice-cream & 0.32 & 0.15 & 0.30 & 0.45 & 106 & Scoops (1) \\
\hline Grilled chicken & 0.30 & 1.19 & 0.00 & 0.95 & 126 & Medium fillet (1.3) \\
\hline Watermelon & 0.27 & 0.11 & 0.40 & 0.10 & 468 & Slices (2.3) \\
\hline Mango & 0.23 & 0.04 & 0.40 & 0.03 & 224 & Large spade type unit (1) \\
\hline Boiled eggs & 0.18 & 0.37 & 0.01 & 0.38 & 45 & Units (1) \\
\hline Total & 90.20 & 93.20 & 89.40 & 90.50 & & \\
\hline
\end{tabular}

Brazilian population. The FFQ is a valuable instrument for fast data collection on a large number of individuals. However, its use has been questioned especially given the low correlation of overall nutrient intake yielded by the FFQ compared with values from gold standard methods 30,31 . This low correlation may be explained by several factors including the ability of interviewee to recall, the high daily variability in intake, and the complex nature of individual diets 32 .

Countering this negative view surrounding the application of the FFQ, there is a consensus that current FFQs yield sufficiently valid information in etiological studies on food-related diseases 33 while the value of FFQ in determining risk levels in epidemiological screening surveys and in guiding public policy is acknowledged 34 . In spite of its limitations, the FFQ can prove of fundamental importance, although the application and use of the instrument should continue to be refined.

The first key aspect of an FFQ is the food items contained in its list of foods. This list should ideally be based on a representative sample of the dietary habits of different strata of the population, since variations in food intake with age, gender and schooling can affect the reproducibility and validity of an FFQ ${ }^{4}$. Indeed, the list of foods in- cluded in an FFQ determines its specificity for the population being assessed. The literature on the theme describes many FFQs which are only applicable for use in specific groups or that have been devised without proper validation. It is also not uncommon to see studies which, using a broad array of criteria attempt to adapt existing questionnaires, validated in other populations, for use in another specific population.

The sample used to generate the list of foods in the present study has advantages over other FFQs validated in Brazil in that it is representative of a particular population and has calibrated sample weights, which produce estimates that correct for the gender and age selection bias. This aspect is important in household surveys because it is extremely difficult to assess the same proportion of men and women, making data calibration of prime importance in achieving an accurate picture of the population. Apparently, only one other FFQ has been produced in Brazil using a representative sample of adults, in this case involving the Municipality of São Paulo 16.

Another notable factor in this study concerns the fact that the data were collected throughout a one-year period, and included monthly assessment of all income brackets of the adult 
population. This strategy enabled seasonality of food intake to be taken into account, despite the theoretically low effect in Niterói owing to its relatively stable weather patterns. This contrasts with the climate in other regions of the country, particularly the South and Northeast regions of Brazil, where droughts mark periods of scarcity.

Another fundamental aspect in devising a list of foods for an FFQ is the number of foods included. The length of this list should be assessed carefully since excessively long questionnaires make the interview tiring ${ }^{4}$ yet questionnaires which are too short may not adequately represent food intake 14 .

Many of the lists for the FFQs validated in Brazil have been described according to food groups. The approach of assessing the effects of food groups or dietary patterns on health can theoretically lead to recommendations concerning the relationship between diet and diseases which are more easily understood by the lay public 4 . However, whenever possible, foods included in the FFQ should be described separately. In the present study the foods were also grouped although being described individually within each group. Overall, the principal differences between the present list of foods consumed by the adult population of Niterói and the other lists from the national literature center on the description of foods such as meat, fruit and vegetables, as well as fat/sugar-rich foods such as desserts, savory snacks and salted biscuits. The intake of these items may differ greatly in the form and frequency they are consumed in different regions of Brazil.

In the present study, several nutritionally similar foods were grouped under a single item, such as the item "lettuce, watercress/rocket". However, three items were created for the several different types of juice: fresh juice - denoting fruit juices prepared directly from the fruit; processed juice - industrialized ready-to-drink juices; and fruit cordials - representing processed juices which require diluting, including lyophilized and liquid forms.

Some fat-rich foods such as bacon found in many national FFQs were not included due to low frequency intake on the 24hR. Furlan-Viebig \& Pastor-Valero 11 considered "bread, cereals, tubers and vegetables" a single group, while the fruit and juice group included foods such as olives and those rich in vegetable oils. The FFQ created by Matarazzo et al. 12 was designed and validated for 26 food items. The food list incorporated in their study comprised items representing a single food, such as beef as well as others representing several foods such as raw vegetables, citric fruits, apples and pears.
The strategy of the present analysis of food intake of the adult population of Niterói included calculating the relative contribution of each of the 143 items (foods/groups) to total intake of energy and macronutrients. Summing the percentage contribution of the foods to energy and macronutrient intake showed that 65 foods accounted for $90 \%$ of energy from macronutrients (43 for protein and 52 for fats). Therefore, a list containing 65 foods explained intake of approximately $90 \%$ of the total intake of energy and macronutrients in the adult population of Niterói. In the study by Fisberg et al. 16, the foods list was drawn up based on dietary intake from $24 \mathrm{hR}$ in 1,477 individuals (aged older than 20 years) in a probabilistic sample of adults from São Paulo city collected in 2003. The 1,040 different foods reported were grouped in two stages to produce three FFQs for use in epidemiological studies involving adult populations. Only foods whose combined contribution exceeded $90 \%$ of total energy and nutrients were retained in the FFQ, producing a list containing a similar number of food items (67) to that determined in the present study.

It is interesting to note that the study by Fisberg et al. 16 found rice to be the greatest contributor to energy intake $(16.4 \%)$, followed by beef $(10.2 \%)$ and bread $(8.7 \%)$. These data were similar to the findings of a more recent Brazilian Household Budget Survey (HBS) 35, which showed that rice $(17.8 \%)$, French bread rolls $(5.45 \%)$ and beef $(5.1 \%)$ were the greatest contributors to total energy of foodstuffs purchased by the Brazilian population, erroneously called "available energy", since "available" includes items held in family food stocks. The data reveals the consistency between the finding of the cited studies and those of the present study. The items that contributed most to total energy were rice, French bread rolls, black beans and refined sugar (10.52\%, $7.45 \%, 5.69 \%$ and $5.35 \%$, respectively). However, the fourth and fifth foods in terms of energy contribution were roasted meat $(4.18 \%)$ and steaks (3.21\%), i.e. $7.39 \%$ of the energy content consisted of beef, replicating findings of other studies. Furthermore, the majority of foods included in the $90 \%$ energy lists used in the study by Fisberg et al. 16 and in the present study are similar. Divergence in the food lists is most likely to be observed for items with a much lower percentage contribution in macronutrients and higher in micronutrients. Differences for some foods which are specific to particular regions or locales in Brazil are also bound to occur.

The present study involved an innovative analysis compared to previously published FFQs by combining the following four differentiating 
characteristics: (1) food intake data were derived from a probabilistic and not a convenient sample; (2) intake data were calibrated for the population, correcting for differences in the proportion of men and women in the population; (3) the dietary intake data took into account seasonality; and (4) intake data were drawn from all income brackets of the population. The foods list created in the present analysis closely resembles the lists used by other studies in samples of adults living in urban regions in the country and should be validated for other urban regions in Brazil. Thus, the application of food questionnaires will allow a list of core foods to be produced, with the inclusion of regional foods, for use in urban regions in Brazil. Identifying the similarities and differences in dietary patterns will allow the consistency of findings to be checked and provide a means of embracing Brazil's cultural and regional diversity regarding food profiles, enabling the construction of a national FFQ with regional specificities.

\section{Resumo}

Com o objetivo de gerar uma lista de alimentos para questionário de freqüência alimentar (QFA), avaliouse dados de recordatório alimentar de 24 horas de um dia típico em uma amostra probabilística de adultos, obtidos num inquérito domiciliar durante o ano de 2003. Verificou-se a freqüência dos alimentos ingeridos, calculou-se o total ingerido de energia e macronutrientes e a contribuição relativa de cada item alimentar no total de energia ou macronutrientes ingeridos. Os dados foram ponderados para representar a população adulta de Niterói, Rio de Janeiro, Brasil. Os alimentos mais ingeridos pelos adultos (> 50\%) foram arroz branco, café, feijão, açúcar refinado e pão fran- cês. Um total de 65 alimentos é capaz de explicar aproximadamente $90 \%$ da ingestão de energia e macronutrientes. A lista de alimentos gerada se assemelha a de outros estudos em amostras de adultos vivendo em regiões urbanas nacionais, e precisa ser validada em outras áreas urbanas do país. É possível que seja gerada uma lista de alimentos comuns, com inclusões de alimentos regionais para ser universalmente usada em QFA nas áreas urbanas do país.

Consumo de Alimentos; Inquéritos sobre Dietas; Métodos Epidemiológicos 


\section{Contributors}

L. A. Anjos and V. Wahrlich planned the study, oversaw field data collection, planned and participated in the data analysis, as well as the discussion of results. M. T. L. Vasconcellos planned the study, designed the sample and calculated the natural and calibrated sample weightings. D. R. Souza oversaw field data collection, calculated food intake, participated in the data analysis, as well as the discussion of results. A. W. Bressan, A. E. P. Lourenço, S. L. Rossato, R. L. Henn, W. Waissmann and M. T. A. Olinto planned and participated in the data analysis and the discussion of results. L. A. Anjos wrote the first draft of the manuscript, the final version of which was reviewed and approved by all the authors.

\section{Acknowledgments}

The Nutrition, Physical Activity and Health Survey (PNAFS) was financially supported by the National Research Council (CNPq; grant $\mathrm{n}^{\circ}$. 471172/2001-4 and 475122/2003-8) and by the Oswaldo Cruz Foundation (Fiocruz; PAPES III - 250.139). The data analysis work was financially supported by CNPq (grant $\mathrm{n}^{\circ}$. 500672/2004-0, 361749/2004-0 and 362105/2004-9) and by the Graduate Studies Coordinating Board (CAPES; PROCAD - grant no. 0257052). L. A. Anjos, M. T. L. Vasconcellos and M. T. A. Olinto received research productivity grants from CNPq (grant $\mathrm{n}^{\circ}$. 311801/2006-4, 302992/2003-0 and 308833/2006-6, respectively). V. Wahrlich received a PhD Grant from CNPq (grant $\mathrm{n}^{\circ}$. 141142/2001-4).

\section{References}

1. World Health Organization. Diet, nutrition and prevention of chronic disease. Geneva: World Health Organization; 2003. (WHO Technical Report Series, 916).

2. World Health Organization. Process for a global strategy on diet, physical activity and health. Geneva: World Health Organization; 2003.

3. Secretaria de Vigilância em Saúde, Ministério da Saúde. Política Nacional de Promoção da Saúde. Brasília: Ministério da Saúde; 2006. (Série B. Textos Básicos de Saúde).

4. Willett WC. Nutritional epidemiology. $2^{\text {nd }}$ Ed. New York: Oxford University Press; 1998.
5. Anjos LA, Souza DR, Rossato S. Desafios na medição da ingestão alimentar quantitativa de populações. Rev Nutr 2009; 22:151-61.

6. Sichieri R, Everhart JE. Validity of a Brazilian food frequency questionnaire against dietary recalls and estimated energy intake. Nutr Res 1998; 18:1649-59.

7. Sichieri R. Epidemiologia da obesidade. Rio de Janeiro: EdUERJ; 1998.

8. Ribeiro AC, Sávio KEO, Rodrigues MLCF, Costa THMC, Schmitz BAS. Validação de um questionário de freqüência de consumo alimentar para a população adulta. Rev Nutr 2006; 19:553-62. 
9. Salvo VL, Gimeno SG. Reprodutibilidade e validade do questionário de frequência de consumo de alimentos. Rev Saúde Pública 2002; 36:505-12.

10. Cardoso MA, Stocco PR. Desenvolvimento de um questionário quantitativo de freqüência alimentar em imigrantes japoneses e seus descendentes residentes em São Paulo, Brasil. Cad Saúde Pública 2000; 16:107-14.

11. Furlan-Viebig R, Pastor-Valero M. Desenvolvimento de um questionário de freqüência alimentar para o estudo de dieta e doenças não transmissíveis. Rev Saúde Pública 2004; 38:581-4.

12. Matarazzo HCZ, Marchioni DML, Figueiredo RAO, Slater B, Eluf Neto J, Wünsch Filho V. Reprodutibilidade e validade do questionário de freqüência de consumo alimentar utilizado em estudo de casocontrole de câncer oral. Rev Bras Epidemiol 2006; 9:316-24.

13. Queiróz AR, Costa CA, Popolim WD, Lima SCTC, Pimentel CVMB, Philippi ST, et al. Avaliação do consumo alimentar pela internet por meio de inquérito de freqüência dietética simplificado. Nutrire Rev Soc Bras Aliment Nutr 2007; 32:11-22.

14. Teixeira MH, Veiga GV, Sichieri R. Avaliação de um questionário simplificado de freqüência de consumo alimentar como preditor de hipercolesterolemia em adolescentes. Arq Bras Cardiol 2007; 88: 66-71.

15. Fornés NS, Stringhini MLF, Elias BM. Reproducibility and validity of a food frequency questionnaire for use among low-income Brazilian workers. Public Health Nutr 2003; 6:821-7.

16. Fisberg RM, Colucci ACA, Morimoto JM, Marchioni DML. Questionário de freqüência alimentar para adultos com base em estudo populacional. Rev Saúde Pública 2008; 42:550-4.

17. Instituto Brasileiro de Geografia e Estatística. Censo demográfico 2000: agregado por setores censitários dos resultados do universo. 2a Ed. Rio de Janeiro: Instituto Brasileiro de Geografia e Estatística; 2003.

18. Bossan FM, Anjos LA, Vasconcellos MTL, Wahrlich V. Nutritional status of the adult population in $\mathrm{Ni}$ terói, Rio de Janeiro, Brazil: the Nutrition, Physical Activity, and Health Survey. Cad Saúde Pública 2007; 23:1867-76.

19. Schlüssel MM, Anjos LA, Vasconcellos MTL, Kac G. Reference values of handgrip dynamometry of healthy adults: a population-based study. Clin Nutr 2008; 27:601-7.

20. Vasconcellos MTL, Silva PLN, Szwarcwald CL. Sampling design for the World Health Survey in Brazil. Cad Saúde Pública 2005; 21 Suppl 1:S89-99.

21. Zabotto CB, Viana RPT, Gil MF. Registro fotográfico para inquéritos dietéticos: utensílios e porções. Campinas: Universidade Estadual de Campinas/ Goiânia: Universidade Federal de Goiás; 1996.
22. Pinheiro ABV, Lacerda EMA, Benzecry EH, Gomes MCS, Costa VM. Tabela para avaliação de consumo alimentar em medidas caseiras. $3 \underline{a}$ Ed. Rio de Janeiro: Editora Atheneu; 2004.

23. Anção MS, Cuppari L, Tudisco ES, Draibe SA, Sigulem D. Sistema de apoio à decisão em nutrição. São Paulo: Escola Paulista de Medicina, Universidade Federal de São Paulo; 1993.

24. Instituto Brasileiro de Geografia e Estatística. Estudo Nacional da Despesa Familiar - ENDEF: tabelas de composição dos alimentos. 4a Ed. Rio de Janeiro: Instituto Brasileiro de Geografia e Estatística; 1996.

25. Franco G. Texto básico e tabela de composição química dos alimentos. 6a Ed. Rio de Janeiro: Editora Atheneu; 1982.

26. Philippi ST. Tabela de composição de alimentos: suporte para decisão nutricional. Brasília: Agência Nacional de Vigilância Sanitária/Fundação de EmpreendimentosCientíficoseTecnológicos/Departamento de Nutrição, Universidade de Brasília; 2001.

27. Ulene A. The Nutribase nutrition facts desk reference: the single encyclopedic source for the most complete, up-to-date and comprehensive collection of food values. New York: Avery Publishing Group; 1995.

28. Silva PLN. Calibration estimation: when and why, how much and how. Rio de Janeiro: Instituto Brasileiro de Geografia e Estatística; 2004. (Textos para Discussão da Diretoria de Pesquisas, 14).

29. Block G, Dresser CM, Hartman AM, Carroll MD. Nutrient sources in the American diet: quantitative data from the NHANES II Survey. II. Macronutrients and fats. Am J Epidemiol 1985; 122:27-40.

30. Kristal AR, Peters U, Potter JD. Is the time to abandon the food frequency questionnaire? Cancer Epidemiol Biomarkers Prev 2005; 14:2826-8.

31. Kristal AR, Potter JD. Not the time to abandon the food frequency questionnaire: counterpoint. Cancer Epidemiol Biomarkers Prev 2006; 15:1759-60.

32. Willett W. Invited commentary: a further look at dietary questionnaire validation. Am J Epidemiol 2001; 154:1100-2.

33. Willett WC, Hu FB. Not the time to abandon the food frequency questionnaire: point. Cancer Epidemiol Biomarkers Prev 2006; 15:1757-8.

34. Block G. Invited commentary: another perspective on food frequency questionnaires. Am J Epidemiol 2001; 154:1103-4.

35. Instituto Brasileiro de Geografia e Estatística. Pesquisa de Orçamentos Familiares 2002-2003: análise da disponibilidade domiciliar de alimentos e do estado nutricional no Brasil. Rio de Janeiro: Instituto Brasileiro de Geografia e Estatística; 2004.

Submitted on 14/May/2009

Final version resubmitted on 30/Mar/2010

Approved on 04/May/2010 